\title{
Preparation and Evaluation of a Novel Class of Amphiphilic Amines as Antitumor Agents and Nanocarriers for Bioactive Molecules
}

\author{
Isabella Orienti ${ }^{\prime}$ • Mirella Falconi ${ }^{2} \cdot$ Gabriella Teti $^{2}$ • MarkA. Currier ${ }^{3}$ • Jiang Wang ${ }^{4}$ - Mitch Phelps ${ }^{4}$. \\ Timothy P. Cripe 3,5
}

Received: 7 March 2016 / Accepted: 11 July 2016 / Published online: 25 July 2016

(C) The Author(s) 2016. This article is published with open access at SpringerLink.com

\begin{abstract}
Purpose We describe a novel class of antitumor amphiphilic amines (RCn) based on a tricyclic amine hydrophilic head and a hydrophobic linear alkyl tail of variable length.

Methods We tested the lead compound, RC16, for cytotoxicity and mechanism of cell death in several cancer cell lines, anti tumor efficacy in mouse tumor models, and ability to encapsulate chemotherapy drugs.
\end{abstract}

Results These compounds displayed strong cytotoxic activity against cell lines derived from both pediatric and adult cancers. The IC50 of the lead compound, RC16, for normal cells including human keratinocytes, human fibroblasts and human umbilical vein endothelial cells was tenfold higher than for tumor cells. RC16 exhibited significant antitumor effects in vivo using several human xenografts and a metastatic model of murine neuroblastoma by both intravenous and oral administration routes. The amphiphilic character of RC16 triggered a spontaneous molecular self-assembling in water with formation of micelles allowing

Electronic supplementary material The online version of this article (doi: | 0. I007/s | 1095-0 16- 1999-9) contains supplementary material, which is available to authorized users.

Timothy P. Cripe

Timothy.Cripe@nationwidechildrens.org

Department of Pharmacy and Biotechnology, University of Bologna, Via S. Donato 19/2, Bologna, Italy

2 Department for Biomedical and Neuromotor Sciences (DIBINEM), University of Bologna, via Irnerio 48, Bologna, Italy

3 Center for Childhood Cancer and Blood Diseases, Nationwide Children's Hospital, Columbus, Ohio, USA

4 College of Pharmacy and Division of Pharmaceutics, The Ohio State University Comprehensive Cancer Center, Columbus, Ohio 432I 0, USA

5 Division of Hematology/Oncology/Blood and Marrow Transplant, Nationwide Children's Hospital, 700 Children's Dr. Columbus, Ohio 43205, USA complexation of Doxorubicin, Etoposide and Paclitaxel. These micelles significantly improved the in vitro antitumor activity of these drugs as the enhancement of their aqueous solubility also improved their biologic availability.

Conclusions RG16 and related amphiphilic amines may be useful as a novel cancer treatment.

KEY WORDS antitumor activity · encapsulation of bioactive molecules in micelles · formation of micelles in water · novel amphiphilic amines · pharmacokinetics and biodistribution

\section{ABBREVIATIONS}

7-AAD 7-amino-actinomycin D

AAALAC Association for Assessment and Accreditation of Laboratory Animal Care

ATCC American Type Culture Collection

DBC 1,7-diazabicyclo [4.4.0] dec-5-ene

DOXO Doxorubicin

ETO Etoposide

FBS fetal bovine serum

HUVECS Human Umbilical Vein Endothelial Cells

i.v. intravenous

IACUC Institutional Animal Care and Use Committee

$\mathrm{IC}_{50}$ half maximal inhibitory concentration

IU international units

IVIS In Vivo Imaging System

LC-MS/ liquid chromatography-tandem mass

MS spectrometry

MTD maximum tolerated dose

MTT 3-(4,5-dimethylthiazol-2-yl)-2,5-diphenyltetrazolium bromide

p.o. oral gavage

PBS phosphate buffered saline

PTX Paclitaxel

ROS reactive oxygen species

RPMI Rosewell Park Medical Institute-1640 media 
RTK

RTV

SDS-

PAGE

SEM

TEM
Receptor Tyrosine-Kinases

$$
\text { relative tumor volume }
$$

SDS polyacrylamide gel electrophoresis

Scanning electron microscopy

transmission electron microscopy

\section{INTRODUCTION}

Newer, targeted antitumor drugs currently in clinical use have improved the outcome of many cancers by exploiting different mechanisms of action to overcome resistance to chemotherapy $(1,2)$. However drug toxicity is often dose limiting, reducing the chance to kill all tumor cells before they develop multidrug resistance. Pediatric tumors in particular represent a serious challenge to chemotherapy as they often grow fast and rapidly develop resistance (3). Also, many types of adult tumors including breast, colon and lung carcinoma frequently fail to respond to therapeutic treatments due to drug resistance $(4,5)$.

Among antitumor agents in development, the lipophilic amines (6) appear particularly interesting. Their mechanism of action is mainly located in mitochondria and lysosomes, unlike inhibitors of DNA, RNA or RTKs that often induce resistance through the expression of P-glycoprotein, multidrug-resistance associated proteins or activation of alternative RTK pathways (7). The alterations in mitochondria and lysosomes that occur in cancer cells (8-18) make the anticancer effect of the lipophilic amines quite specific. A major drawback to their clinical use, however, is their high hydrophobicity, which restrains their bioavailability and consequently their therapeutic efficacy.

We hypothesized that amphiphilic amines ( $\mathrm{RCn}$ ) whose molecular structure comprises a tricyclic amine hydrophilic head and a hydrophobic linear alkyl tail of variable length would be harmful to cancer cells and serve as drug-delivery vehicles. Our primary objective was to determine the antitumor activity of these novel agents alone in both pediatric and adult cell lines and animal tumor models. Mice were used because of the availability of human tumor xenograft models. Our secondary objective was to determine the ability of these agents to be complexed with other anticancer agents such as chemotherapy. Thus, $\mathrm{RC}_{16}$ was also evaluated as a nanocarrier for bioactive molecules as, due to its amphiphilic character, it spontaneously self-assembles in water into micelles able to complex hydrophobic drugs.

\section{MATERIALS AND METHODS}

\section{Materials}

DBC was purchased from Sigma-Aldrich. All the other reagents and solvents for the synthesis of the amphiphilic amines were purchased from Fluka.

\section{Cell Lines}

Human cancer cell lines 143.98.2, A673, A549, CHLA20, S462TY and Ramos have been previously described (19-22). Normal primary HUVECs, Human Foreskin Keratinocytes (differentiated) were also previously described (22,23). Alveolar rhadomyosarcoma cell line Rh41 was obtained from the Pediatric Preclinical Testing Program (Peter Houghton, Nationwide Children's Hospital) and maintained in RPMI supplemented with 10\% fetal bovine serum (FBS), lglutamine, and $100 \mathrm{IU} / \mathrm{ml}$ penicillin and $100 \mu \mathrm{g} / \mathrm{ml}$ streptomycin. Murine neuroblastoma cell line Neuro2A, normal gingival fibroblasts (24), and the human cancer cell lines SK-NAS (neuroblastoma), MDA-MB-231 (breast) and WIDr (colon adenocarcinoma) were purchased from ATCC (Manassas, VA). All cells purchased from the ATCG were maintained according to supplier instructions.

\section{Animal Studies}

All animal studies were approved by the IACUC at Cincinnati Children's Hospital Medical Center (prior to the lab's relocation to Nationwide Children's Hospital). Athymic nude (nu/nu) and A/J female mice, 4-6 weeks old, weighing 20-25 g were purchased from Harlan Sprague Dawley (Indianapolis, IN). Athymic nude mice were used to determine $\mathrm{RG}_{16}$ maximum tolerated dose, pharmacokinetics, drug biodistribution and efficacy in xenograft tumor models. A/J mice were used to determine efficacy in an immunocompetent tumor model. Animals were housed 4 mice/cage in the Cincinnati Children's Hospital Medical Center AAALAC accredited facility. Mice were kept in specific pathogen free rooms, which maintain constant temperature, humidity, and light/dark cycle. Animals were observed daily by the animal care staff including weekends. A full-time veterinarian was available to ensure adequate veterinary care. Animals were provided water and chow ad libitum. Cages and bedding were changed once/week and all cages were maintained in racks with independent sterile water and hepa-filtered airflow.

\section{Determination of the Maximum Tolerated Dose in Mice}

To determine the MTD, a standard assay dose escalation study was performed. Non-tumor bearing, female, athymic nude mice were injected once with $\mathrm{RG}_{16}$ by the tail vein starting with $0.5 \mathrm{mg} / \mathrm{kg}$. The doses were escalated by $0.25 \mathrm{mg} / \mathrm{kg}$ until MTD was achieved. Following convention, each dose was tested on a cohort of 5 mice in individual independent experiments. MTD was defined as the highest dose that could be given resulting in no drug-related moribund state or death or body weight loss $\geq 20 \%$ in the first 7 days. Other signs of toxicity such as unusual mouse behavior, lack of movement and poor posture were also monitored. Mice were 
weighed and observed 3 times per week for any signs of toxicity. Mice that demonstrated signs of toxicity were humanely euthanized by $\mathrm{CO}_{2}$ asphyxiation.

\section{Pilot Pharmacokinetic Study in Mice}

To establish a standard assay for $\mathrm{RC}_{16}$ detection and the halflife of $\mathrm{RC}_{16}$ in murine blood, a basic pilot pharmacokinetic study was performed using 1 animal per timepoint. Nontumor bearing, female, athymic nude mice were treated with $\mathrm{RC}_{16}$ by i.v. or p.o.at doses of $1 \mathrm{mg} / \mathrm{kg}$ and $2 \mathrm{mg} / \mathrm{kg}$, respectively. At 2, 4, 6, 12, 24 and $48 \mathrm{~h}$ post $\mathrm{RC}_{16}$ administration, a single mouse was anesthetized in an induction chamber with $5.0 \%$ isoflurane and an $\mathrm{O}_{2}$ flow rate of $0.8 \mathrm{~L} / \mathrm{min}$. Each mouse was transferred to a nose cone supplying $5.0 \%$ isoflurane with a $\mathrm{O}_{2}$ flow rate of $0.8 \mathrm{~L} / \mathrm{min}$. After confirming sedation by testing hind footpads, each mouse was subjected to exsanguination by cardiac puncture. Blood samples were collected in BD Microtainers (BD, Franklin Lakes, NJ). Plasma was separated by centrifugation at $2000 \times \mathrm{g}$ for $10 \mathrm{~min}$ at $4^{\circ} \mathrm{C}$ and stored at $-80^{\circ} \mathrm{C}$ until analysis. The $\mathrm{RC}_{16}$ concentration in plasma was determined by liquid LC-MS/MS.

\section{Biodistribution Study}

A pilot biodistribution study using one animal per timepoint was performed to minimize the number of experimental animals. Female athymic nude mice were subcutaneously implanted with $5.0 \times 10^{6} \mathrm{CHLA}-20$ cells. When tumors became palpable (approximately $5 \mathrm{~mm}$ in diameter), mice were treated with i.v. injections of $\mathrm{RC}_{16}$ labelled with Cell-Vue Maroon (dye: $\left.\mathrm{RC}_{16}, 1: 100 \mathrm{~mol}: m o l e\right)$ at a dose of $1 \mathrm{mg} / \mathrm{kg}$. At 12, 24 and $36 \mathrm{~h}$ post $\mathrm{RC}_{16}$ injection, drug biodistribution was determined using the IVIS-200 (PerkinElmer, Waltham, MA) with filter sets at 760/800 nm (excitation/emission). The mice were then humanely euthanized by $\mathrm{CO}_{2}$ asphyxiation. Organs were removed, weighed and used for quantitative optical imaging by the IVIS system.

\section{In Vivo Efficacy Study}

\section{Xenograft Models}

Female athymic nude mice were subcutaneously injected with $5 \times 10^{6}$ human cancer cells in $150 \mu \mathrm{L}$ mix of PBS and matrigel (2:1). The mice were then randomized into groups of six animals for each tumor type. This number was chosen because we sought a large effect size and to minimize numbers of mice. When tumors reached a mean volume of $150 \mathrm{~mm}^{3}$, the animals were treated with $\mathrm{RC}_{16}$ or vehicle alone (PBS), given slowly through the tail vein at the dose of $1 \mathrm{mg} / \mathrm{kg}, 3$ times a week for 3 weeks or orally gavaged at the dose of $2 \mathrm{mg} / \mathrm{kg} /$ day for 3 weeks.

\section{Immunocompetent Model}

An efficacy study was performed on an immunocompetent model of neuroblastoma. In this experiment $\mathrm{A} / \mathrm{J}$ mice were i.v. injected with Neuro 2A $\left(0.2 \times 10^{6}\right.$ cells in $100 \mu \mathrm{L}$ of PBS $)$. After 5 days, the mice were randomized (six animals per group) and treated once with $\mathrm{RC}_{16}$ injected through the tail vein at doses of $20 \mu \mathrm{g}$ or $40 \mu \mathrm{g} / \mathrm{mouse}$ or vehicle (PBS). After treatment animals were monitored for survival and endpoint criteria.

\section{Endpoint Criteria}

Endpoint criteria included tumor volume $>2000 \mathrm{~mm} 3$, body weight loss $\geq 20 \%$, unusual mouse behavior, lack of movement and poor posture. Tumor size was measured using digital calipers on alternate days and tumor volume was calculated using the following formula: $\mathrm{a} \mathrm{x}^{2} \pi / 6$ where $\mathrm{a}$ is the longest diameter and $b$ is the shortest diameter. Mice were also weighed and observed 3 times per week for signs of endpoint condition. Mice that demonstrated signs of toxicity or reached endpoint criteria were humanely euthanized by $\mathrm{CO}_{2}$ asphyxiation.

\section{In Vitro Cell Proliferation Assays}

Cells were plated in 96-well tissue culture plates at a density of $1 \times 10^{3}$ cells/well, allowed to attach $24 \mathrm{~h}$, and then left untreated or treated with growth medium containing different concentrations of the tested RCn compounds previously dissolved in PBS. After different time periods the cell vitality was determined by MTT assay according to the manufacture's instruction (Promega). Results are reported as the micromolar concentration of $\mathrm{RCn}$ reducing cell survival to $50 \%\left(\mathrm{IC}_{50}\right)$.

\section{Western Blot Analysis}

Cells with or without $\mathrm{RC}_{\mathrm{n}}$ treatment were washed with PBS and lysed on ice for $30 \mathrm{~min}$ in lysis buffer containing protease and phosphatase inhibitors. Protein concentrations were determined with the Bio-Rad protein assay kit. $50 \mu \mathrm{g}$ of total protein was separated on $12 \%$ SDS-PAGE at $100 \mathrm{~V}$ for $1 \mathrm{~h}$ and then transferred onto a nitrocellulose membrane using a wet blotting apparatus (Bio-Rad Laboratories) at $20 \mathrm{~V}$ overnight. Proteins were detected by enhanced chemiluminescence detection reagents (Amersham Biosciences). The antibodies used for immunoblotting were: caspases 3, 8, 9, and PARP were diluted 1:100 in blocking reagent (Cell Signaling Technology). The exposure time was the same for all the antibodies. Blots were stripped and reprobed with anti- $\beta$ - 
tubulin diluted 1:10,000 in blocking reagent (Santacruz Biotechnology) used as the loading control.

\section{Caspase Activity Assays}

Detection of caspase activity was evaluated by ApoFluor Green Apoptosis Detection kits specific for: caspase-1 and caspase-4; caspase-2, caspase-3 and caspase-7; caspase-6, caspase-8, caspase-9, caspase-10, and caspase-13 (MP Biochemicals), according to the manufacturer's instructions. Briefly, 5000 cells in 96-well microplates were detached with EDTA and centrifuged at $400 \times \mathrm{g}$ for $5 \mathrm{~min}$ at room temperature. Cell supernatants were removed, and the pellets resuspended in a buffer containing the appropriate caspase-specific fluorescent probe. After $1 \mathrm{~h}$ incubation samples were washed and analyzed by flow cytometry (FACScan, Becton Dickinson) equipped with a $15-\mathrm{mW}$ argon ion laser at $488 \mathrm{~nm}(16)$.

\section{Flow Cytometric Analysis}

SH-SY5Y, A673 and 143.98.2 cells were stained with Annexin V-FITC/7AAD according to the manufacturer's instructions (Biosciences). Briefly, adherent cells were seeded in 6 multi wells at a concentration of $4.5 \times 10^{5}$ cells/well and after $24 \mathrm{~h}$ treated with $5 \mu \mathrm{M} \mathrm{RG}_{16}$ for $15 \mathrm{~h}$ and $24 \mathrm{~h}$. At the end of the treatment the cells were detached, washed twice with cold PBS and then suspended in annexin binding buffer containing $5 \mu \mathrm{l}$ of Annexin V-FITC and $5 \mu \mathrm{l}$ of 7AAD. The samples were gently vortexed and incubated $15 \mathrm{~min}$ at $25^{\circ} \mathrm{C}$ in the dark. Finally, 400 ul binding buffer were added to each tube and the samples were analyzed by BD LSR II (Biosciences). The analysis was performed by FlowJo software version 10.0.5.

\section{Measurement of Intracellular ROS}

Intracellular ROS were measured by OxiSelect ${ }^{\mathrm{TM}}$ Intracellular ROS Assay Kit (Cell Biolabs) following the manufacturer's instructions. Briefly, cells $\left(1 \times 10^{5} / \mathrm{mL}\right)$ were washed twice in PBS and incubated with $5 \mu \mathrm{M} 2$ ', 7'dichlorodihydrofluorescein diacetate $\left(\mathrm{H}_{2} \mathrm{DCFDA}\right) 1 \mathrm{~h}$ at $37^{\circ} \mathrm{C}$. After PBS washes, the medium was changed with a

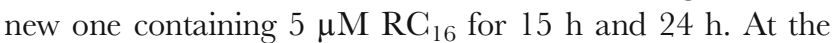
end of the treatment samples were washed with PBS and a mixture of medium and cell lysis buffer (1:1) was added for $5 \mathrm{~min}$ at $37^{\circ} \mathrm{C}$. The fluorescence was read by a fluorimetric plate reader (Spectra max M2, Molecular Device). Excitation wavelength was $480 \mathrm{~nm}$ and emission wavelength was $530 \mathrm{~nm}$.

\section{Electron Microscopy}

\section{TEM Studies}

TEM studies were carried out on SH-SY5Y cells and HFs incubated with $5 \mu \mathrm{M} \mathrm{RG}_{16}$ for $24 \mathrm{~h}$. Cells were seeded on cover glasses for $24 \mathrm{~h}$ and then the medium was replaced with a fresh one containing $5 \mu \mathrm{M} \mathrm{RC}_{16}$ for $24 \mathrm{~h}$. At the end of the treatment the samples were washed with PBS and fixed with $2.5 \%$ glutaraldehyde in $0.1 \mathrm{M}$ phosphate buffer for $2 \mathrm{~h}$ at $4^{\circ} \mathrm{C}$ and subsequently post-fixed with $1 \% \mathrm{OsO}_{4}$ in $0.1 \mathrm{M}$ phosphate buffer for $1 \mathrm{~h}$ at room temperature. After several washes the samples were dehydrated in an acetone series (70, 90, 100\%) and embedded in Epon resin (Fluka, Sigma-Aldrich). Thin sections were collected on nickel grids, stained with uranyl acetate and lead citrate, and observed under a TEM (Philips CM10; FEI). Images were recorded using a Megaview III digital camera (FEI). TEM was also used to prove the formation of micelles in an aqueous environment due to the amphiphilic nature of the RCn molecules. To this purpose an aqueous solution of $\mathrm{RC}_{16}(20 \mu \mathrm{M})$ was stained with $2 \%(\mathrm{w} / \mathrm{v})$ phosphotungstic acid for $3 \mathrm{~min}$ on a copper grid and subsequently it was visualized under TEM.

\section{SEM Studies}

SH-SY5Y cells were seeded on holders for $24 \mathrm{~h}$ and then the medium was replaced with a fresh one containing $20 \mu \mathrm{M} \mathrm{RG}_{16}$ for $1 \mathrm{~h}$. At the end of the treatment the samples were washed with PBS and fixed for SEM in 2.5\% glutaraldehyde, then dehydrated in an ethanol series (70, 90, 100\%) and critical point dried. The dried specimens were sputter-coated with carbon and examined by FESEM (JSM 890, Jeol). The aqueous solution of $\mathrm{RC}_{16}(20 \mu \mathrm{M})$ was desiccated at RT on the sample holder, coated with carbon and examined by FESEM.

\section{Interaction of $\mathbf{R C}_{16}$ with Sialic Acid}

Neuraminidase was used to cleave the sialic acid residues from the polysialilated glycoproteins and gangliosides of the tumor cell surface and the anticancer activity of $\mathrm{RC}_{16}$ was subsequently tested in comparison with the cells not exposed to Neuraminidase. Cells were seeded on 96 well plates at a density of $2 \times 10^{4}$ cells / plate and after $24 \mathrm{~h}$ were exposed to 50 IU/mL Neuraminidase Type VI from Clostridium Perfrigens (Sigma) for $3 \mathrm{~h}$. Cells were washed 3 times with PBS and afterwards treated with $\mathrm{RG}_{16}$. The effect on cell number was evaluated after $24 \mathrm{~h}$ by MTT assay in comparison with cells not treated with Neuraminidase. The $\mathrm{RC}_{16}$ sialic acid interaction was also evaluated by adding sialic acid to the culture medium in stoichiometric amount with respect to $\mathrm{RG}_{16}$. In this experiment cells seeded on 96 well plates at a density of $2 \times 10^{4}$ cells / plate and after $24 \mathrm{~h}$ were treated with 
a mixture of $\mathrm{RG}_{16}$ : sialic acid $(3 \mu \mathrm{M}: 3 \mu \mathrm{M})$. After $24 \mathrm{~h}$ the effect on cell number was evaluated by MTT assay in comparison with cells treated with pure $\mathrm{RC}_{16}$ or pure sialic acid at the same concentration $(3 \mu \mathrm{M})$ of the mixture.

\section{LC-MS/MS Analysis}

Chromatographic separation was achieved using a Thermo Scientific Accela UHPLC system with HTS PAL autosampler and an Agilent ZORBAX Extend C18 column $(50 \times 2.1 \mathrm{~mm}$ I.D, $3.5 \mu \mathrm{m}$ particle size) with a C18 guard cartridge maintained at $35^{\circ} \mathrm{C}$. A 6.0 min linear gradient program with water $/ 0.3 \%$ formic acid as mobile phase A and acetonitrile/ $0.3 \%$ formic acid as mobile phase $\mathrm{B}$ at a constant flow rate of $400 \mu \mathrm{L} / \mathrm{min}$ was applied for elution: $0.0 \mathrm{~min} 25 \% \mathrm{~B}, 1.0 \mathrm{~min}$ $25 \%$ B, 3.0 min $95 \%$ B, $4.5 \min 95 \%$ B, 4.6 min $25 \%$ B and $6.0 \mathrm{~min} 25 \% \mathrm{~B}$. The autosampler sample draw was set to $4^{\circ} \mathrm{C}$, and a divert valve was used (0.0-2.0 $\mathrm{min})$ to prevent early eluting compounds from entering the MS. Selective reaction monitoring with unit resolution was used for MS detection under positive mode. Transition channels from the protonated molecular ion to selected product ion were $377.33>153.15$ for $\mathrm{RC}_{16}$ and $251.20>153.15$ for internal standard $\mathrm{RC}_{7}$, respectively. Parameters optimized with a direct infusion of analyte and IS using a syringe pump were as follows: spray voltage, $5000 \mathrm{~V}$; sheath gas and auxiliary gas, 25 and 15 (arbitrary unit), respectively; capillary temperature, $325^{\circ} \mathrm{C}$; collision gas pressure, $1.5 \mathrm{~m}$ Torr and skimmer offset, $10 \mathrm{eV}$. Tube lens offset was $100 \mathrm{eV}$ for both $\mathrm{RC}_{16}$ and $\mathrm{RC}_{7}$, respectively. Scan time was 0.03 s. Collision energies were $40 \mathrm{eV}$ for $\mathrm{RC}_{16}$ and $33 \mathrm{eV}$ for $\mathrm{RC}_{7}$. Thermo Scientific LCQuan software was employed for system control and data processing.

\section{Ability of the RCn Micelles to Encapsulate Bioactive Molecules}

Aqueous solutions of $\mathrm{RC}_{16}(10 \mathrm{mM}, 1 \mathrm{~mL})$ were mixed with ethanol solutions of Doxorubicin, Paclitaxel or Etoposide $(1 \mathrm{mM}, 1 \mathrm{~mL})$. After stirring $12 \mathrm{~h}$ at $25 \mathrm{C}$ the mixtures were dialyzed through 5000 Da MW cutoff dialysis membranes against $100 \mathrm{ml}$ water by changing the external medium every $8 \mathrm{~h}$ for 3 days. The $\mathrm{RC}_{16}$-drug complex collected after dialysis was freeze-dried and the solid residue obtained was spectrophotometrically analysed to estimate the percentage of drug in the final product. The anticancer activity of each complexed drug was evaluated in CHLA-20 as the difference between the activity of the complex and the pure $\mathrm{RG}_{16}$ at the same concentration of the complex.

\section{Statistical Analysis}

For the in vitro assays, all data points represent mean $\pm \mathrm{SD}, n=6$ wells. All the experiments were repeated at least 3 times.
Representative data are shown. Statistical significance among the mean values was analysed via an unpaired two-tailed Student $t$-test assuming equal variance. For in vivo efficacy studies, $n=6$ animals. Six was determined to be the minimal number of animals necessary to be able to detect a large effect size. For relative tumor volume (RTV), statistical significance among the mean values was analysed via an unpaired two-tailed Student $t$-test assuming equal variance. Survival statistical significance was determined using the Log-Rank (Mantel-Cox) test on Graph Pad Prism (La Jolla, CA). The significance (pvalue) was set at the nominal level of 0.05 or less.

\section{RESULTS}

\section{Synthesis of the Amphiphilic Amines}

The amphiphilic amines were synthesized following the scheme described in Fig. 1. A mixture of 1,8diazabicyclo[5.4.0] undec-7-ene (DBU) and the appropriate alkene (in a 1:3 Molar ratio) in N-methylpyrrolidone was stirred at room temperature $4 \mathrm{~h}$ in the presence of 2-[2-(ethenyloxy)ethoxy] ethan-1-ol $0.2 \mathrm{M}$ as a catalyst. Addition of diethylether induced the precipitation of a solid residue that was purified by flash chromatography using a mixture of methanol/water (9:1) as eluent. The final products were characterized by ${ }^{1} \mathrm{H}$ NMR, ${ }^{13} \mathrm{C}$ NMR, mass spectra, and elemental analysis (Supplemental Material).

\section{In Vitro Cell Killing}

Time-dependent and dose-dependent cell killing was observed in the presence of all the RCn compounds of the series (Table I). Differences in activity were obtained among the different $\mathrm{RCn}$ with $\mathrm{RG}_{16}$ resulting the most active against all the pediatric tumor cell lines analyzed (Table I). Under light microscopy, cells showed characteristic morphologic changes consistent with cell death (Fig. 2). Due to its improved antitumor activity, $\mathrm{RC}_{16}$ was further evaluated on a set of adult tumor cell lines (A549, MDAMB-231, WiDr) selected for being particularly resistant to the current antitumor treatments. $\mathrm{RC}_{16}$ was very active with $\mathrm{IC}_{50}$ values in the low micromolar range $(1-10 \mu \mathrm{M}$, Table III). The evaluation $\mathrm{RC}_{16}$ on the normal cell lines demonstrated, on the contrary, very low potency with $\mathrm{IC}_{50}$ values for human keratinocytes, human fibroblasts and HUVEC more than tenfold higher than those for tumor cells (Table II).

\section{Induction of Apoptosis}

We tested the ability of $\mathrm{RC}_{16}$ for the induction of apoptosis. As shown in Fig. 3a control and treated cells were gated into LR (Lower Right), UR (Upper Right), LL (Lower Left) and UL (Upper Left) quadrants. Cells in LR and UR were considered 

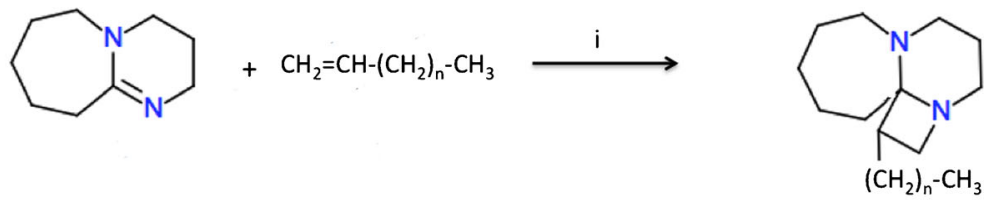

1:n=4. $\left(\mathrm{RC}_{7}\right):$ 2-pentyl-4,8-diazatricyclo[6.5.0.0 $\left.{ }^{14},{ }^{4}\right]$ tridecane

2:n=7. $\left(\mathrm{RC}_{10}\right): 2$-octyl-4,8-diazatricyclo[6.5.0.0 $\left.{ }^{1}{ }^{4}\right]$ tridecane

3:n=9. $\left(\mathrm{RC}_{12}\right): 2$-decyl-4,8-diazatricyclo[6.5.0.0 $\left.0^{14},{ }^{4}\right]$ tridecane

$4: \mathrm{n}=11 .\left(\mathrm{RC}_{14}\right): 2$-dodecyl-4,8-diazatricyclo[6.5.0.0 $\left.{ }^{14}\right]$ tridecane

$5: n=13 .\left(R_{16}\right): 2$-tetradecyl-4,8-diazatricyclo[6.5.0.0 $\left.0^{14},\right]$ tridecane

6:n=15. $\left(\mathrm{RC}_{18}\right): 2$-hexadecyl-4,8-diazatricyclo[6.5.0.0 $\left.{ }^{14},\right]$ tridecane

7:n=17. $\left(\mathrm{RC}_{20}\right): 2$-octadecyl-4,8-diazatricyclo[6.5.0.0 $\left.0^{14}\right]$ tridecane

Fig. I Schema for the synthesis of RCn compounds. (i) N-methylpyrrolidone (NMP), 2-[2-(ethenyloxy)ethoxy]ethan- $-\mathrm{ol} \mathrm{CH} 2=\mathrm{CH}_{-}\left(\mathrm{O}_{-}-\mathrm{CH}_{2} \mathrm{CH}\right)_{2}-\mathrm{OH}$ as a catalyst, $4 \mathrm{~h}$, room temperature.

as early apoptotic (annexin+/7AAD-) and late apoptotic (annexin+/7AAD+) respectively. Cells in LL and UL were considered live (annexin-/7AAD-) and necrotic (annexin-/ 7AAD+), respectively. Flow cytometric analysis showed that the percentage of cells in apoptosis increased over time with differences among the different cell lines. At $15 \mathrm{~h}$ the extent of apoptosis expressed as the sum of the percentages in LR and UR quadrants was higher in A673 and lower in 143.98.2. After $24 \mathrm{~h}$ all the cells showed approximately $100 \%$ apoptosis. These data indicate the apoptotic mode of cell death in all the cell lines analyzed and a different rapidity of cell death depending on the cell type. Differences between control and treated cells are statistically significant at any time of treatment ( $p=0.016$ vs control). To further confirm the apoptotic nature of cell death induced by $\mathrm{RC}_{16}$ in tumor cells, we also evaluated whether caspases were involved in the death process. We performed both western blot analysis and fluorimetric assays on SH-SY5Y cells in the presence of $\mathrm{RC}_{16}$. The western blot analysis indicated activation of caspases 3,8 and 9 after exposure to $\mathrm{RC}_{16}$ (Fig. 3b), suggesting the induction of both extrinsic and intrinsic apoptosis. In the fluorimetric assays we used different commercially available kits for single caspases (i.e., caspase-1, caspase-2, caspase-3, caspase-6, caspase-8, caspase-9, caspase-10, and caspase-13) and measured the increase in fluorescence after 1, 2, 4, 6, 12, and $24 \mathrm{~h}$ in $\mathrm{SH}$ SY5Y cells exposed to $\mathrm{RC}_{16}$. As shown in Fig. 3c all the above caspases were activated already at $4 \mathrm{~h}$ and became more active thereafter in treated tumor cells with respect to controls.

\section{Electron Microscopy Analysis of RCI6 Treated Cells and the Encapsulation Ability of $R_{16}$ Micelles Towards Bioactive Molecules}

SH-SY5Y cells treated with $\mathrm{RC}_{16}$ for $24 \mathrm{~h}$ showed a polygonal morphology in which nucleus and nucleolus were well preserved while cytoplasm was characterized by several vacuoles of different diameters (Fig. 4a). At higher magnification damaged mitochondria with no clear cristae were easily detected

Table I Cell killing activity of RCn compounds on pediatric tumor cell lines (IC50 $(\mu \mathrm{M}))$ at 24 and $48 \mathrm{~h}$ *

\begin{tabular}{|c|c|c|c|c|c|c|c|c|c|c|c|c|c|c|c|}
\hline \multirow[t]{2}{*}{ Cell Line } & \multirow[t]{2}{*}{ Tissue Type } & \multicolumn{2}{|l|}{$\mathrm{RC}_{7}$} & \multicolumn{2}{|l|}{$\mathrm{RC}_{10}$} & \multicolumn{2}{|l|}{$\mathrm{RC}_{12}$} & \multicolumn{2}{|l|}{$\mathrm{RC}_{14}$} & \multicolumn{2}{|l|}{$\mathrm{RC}_{16}$} & \multicolumn{2}{|l|}{$\mathrm{RC}_{18}$} & \multicolumn{2}{|l|}{$\mathrm{RC}_{20}$} \\
\hline & & $24 \mathrm{~h}$ & $48 \mathrm{~h}$ & $24 \mathrm{~h}$ & $48 \mathrm{~h}$ & $24 \mathrm{~h}$ & $48 \mathrm{~h}$ & $24 \mathrm{~h}$ & $48 \mathrm{~h}$ & $24 \mathrm{~h}$ & $48 \mathrm{~h}$ & $24 \mathrm{~h}$ & $48 \mathrm{~h}$ & $24 \mathrm{~h}$ & $48 \mathrm{~h}$ \\
\hline A673 & Ewing's Sarcoma & 5.73 & 4.11 & 2.60 & 2.02 & 1.82 & 1.65 & 1.27 & 1.13 & 0.80 & 0.65 & 1.03 & 0.98 & 1.22 & 1.35 \\
\hline | 43.98 .2 & Osteosarcoma & 4.51 & 3.78 & 2.55 & 1.68 & 1.98 & 1.24 & 1.31 & 0.78 & 0.50 & 0.32 & 0.92 & 0.65 & 1.09 & 0.83 \\
\hline SK-N-AS & Neuroblastoma & 5.21 & 3.43 & 2.14 & 1.56 & 1.87 & 0.71 & 1.20 & 0.63 & 0.88 & 0.67 & 1.23 & 0.75 & 1.60 & 0.90 \\
\hline S462TY & $\begin{array}{l}\text { Malignant Peripheral } \\
\text { Nerve Sheath Tumor }\end{array}$ & 5.62 & 3.90 & 2.39 & 1.78 & 2.00 & 1.09 & 1.81 & 0.95 & 1.11 & 0.76 & 1.67 & 0.88 & 1.83 & 1.16 \\
\hline Ramos & Lymphoma & 4.55 & 3.12 & 2.10 & 1.03 & 1.18 & 0.74 & 0.96 & 0.22 & 0.10 & 0.04 & 0.83 & 0.17 & 0.97 & 0.20 \\
\hline Rh4I & Rhabdomyosarcoma & 5.78 & 4.01 & 2.85 & 2.03 & 1.75 & 1.16 & 1.36 & 0.97 & 0.25 & 0.15 & 1.01 & 0.82 & 1.68 & 1.12 \\
\hline
\end{tabular}

* Data are representative of three independent experiments 

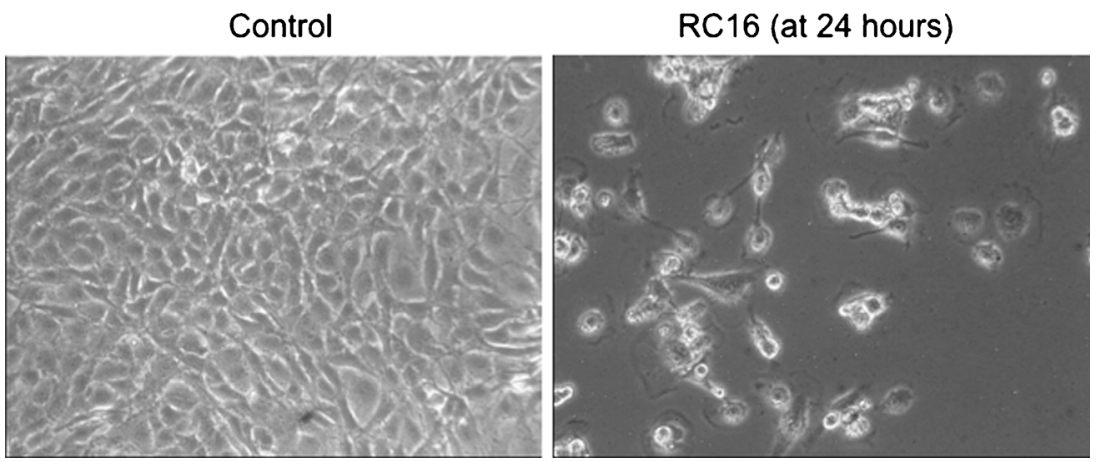

Fig. 2 Light microscopy analysis of I 43.98.2 tumor cells treated for $24 \mathrm{~h}$ with $5 \mathrm{uM} \mathrm{RCI6}$. The cells appeared reduced in the number, rounded in shape and almost detached from the plastic surface of the flask. All these morphological features are consistent with cell death (magnification I0X). Similar findings were observed in all other cancer cell lines treated with $\mathrm{RCl} 6$.

as well as late autophagy vacuoles (lysosome like vacuoles) with materials at different stages of degradation. Damaged rough endoplasmic reticulum and multilamellar bodies connected with phospholipid degradation were also observed (Fig. 4a). Human fibroblasts treated with $\mathrm{RC}_{16}$ at the same concentration and duration showed a fibroblastic morphology and a nucleus well preserved (Fig. 4b). Several small vacuoles were detected in the cytoplasm. Normal mitochondria were observed, while some autophagy vacuoles connected with an early process were detected (Fig. 4b). The formation of micelles, triggered by the spontaneous self-assembling of the amphiphilic $\mathrm{RC}_{16}$ molecules in water, was confirmed by Electron Microscopy. SEM and TEM images of $\mathrm{RC}_{16}$ in the presence of SH-SY5Y cells displayed micelles of spherical shape and regular surface (Fig. 4c, d). Measure of their mean diameter, performed by TEM, provided values in the nanometric range (20-30 nm). The $\mathrm{RC}_{16}$ micelles were able to encapsulate the antitumor drugs studied. The encapsulation efficiency, calculated as the weight percentage of drug in the final complex, followed the order: Doxorubicin $(2.3 \pm 0.78 \%)>$ Paclitaxel $(1.8 \pm 0.73 \%)>$ Etoposide $1.0 \pm 0.59 \%)$. The anticancer activity of the complexed drugs resulted in each case higher than the free drugs at the same concentrations of the complex. The highest improvement in anticancer activity with respect to the free drug was observed in the presence of Doxorubicin (Table III).

\section{Evaluation of Intracellular ROS and the Interaction of $\mathrm{RC}_{16}$ With Sialic Acid}

The evaluation of intracellular ROS confirmed the damage to mitochondria observed by electron microscopy. After treatment with $\mathrm{RC}_{16}$, intracellular ROS increased in all the tumor cell lines analysed. The highest increase was observed in A673 where the ROS levels became more than twice the control values after $15 \mathrm{~h}$ of cell exposure to $\mathrm{RC}_{16}$ (Fig. 5a). In $\mathrm{SH}$ SY5Y and 143.98.2 the ROS increase occurred after longer time periods ( $24 \mathrm{~h}$ ) of cell exposure to $\mathrm{RC}_{16}$ with lower level increase relative to the controls.
The pre-treatment of cells with Neuraminidase, decreasing the presence of sialic acid on the glycoproteins and gangliosides of the cell surface, decreased the anticancer activity of $\mathrm{RC}_{16}$ (Fig. 5b) supporting the hypothesis of an interaction of $\mathrm{RC}_{16}$ with the sialic acid residue of the cell membrane as a contribution to its whole mechanism of action. As confirmation, the addition of sialic acid to the culture medium, interacting with $\mathrm{RC}_{16}$ and therefore decreasing its availability towards the sialic acid residues present on the glycoproteins and gangliosides of the tumor cell surface, decreased the $\mathrm{RC}_{16}$ anticancer activity (Fig. 5c).

\section{Maximum Tolerated Dose in Mice}

Prior to initiation of the experiment, animals were naïve to drug and weighed an average of $0.023 \mathrm{~kg}$. The maximum tolerated dose of $\mathrm{RC}_{16}$ by intravenous route was $4 \mathrm{mg} / \mathrm{kg}$. At this dose 5/5 (100\%) survival was obtained with no body weight loss with respect to the controls. Moreover, no signs of toxicity such as altered mouse behavior, movement or diarrhea were observed. By increasing the dose above $4 \mathrm{mg} / \mathrm{kg}$ a progressive decrease in survival was observed with a $0 / 5(0 \%)$ survival at $5.5 \mathrm{mg} / \mathrm{kg}$.

Table II Cell killing activity of R- $\mathrm{C}_{16}$ on adult tumor and normal cell lines $(\mathrm{IC} 50(\mu \mathrm{M}))$ at 24 and $48 \mathrm{~h})^{*}$

\begin{tabular}{lll}
\hline Adult Tumor Cell Line & $\mathbf{2 4} \mathbf{~ h}$ & $\mathbf{4 8} \mathbf{h}$ \\
A549 & 6.62 & 5.58 \\
MDA-MB-23I & 2.96 & 1.67 \\
WIDr & 7.30 & 6.02 \\
Normal Cell Lines & $\mathbf{2 4} \mathbf{h}$ & $\mathbf{4 8} \mathbf{h}$ \\
Human Foreskin Keratinocytes (differentiated) & 15.20 & 13.46 \\
Human Gingival Fibroblasts & 11.80 & 10.50 \\
HUVEC & 10.63 & 9.65 \\
\hline
\end{tabular}

*Data are representative of three independent experiments 
a

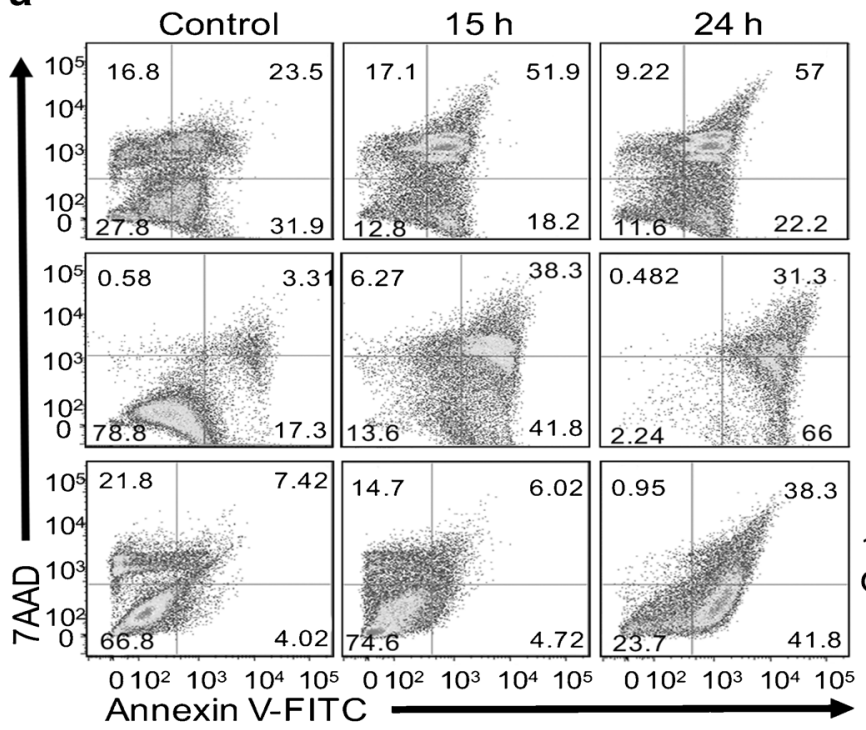

b

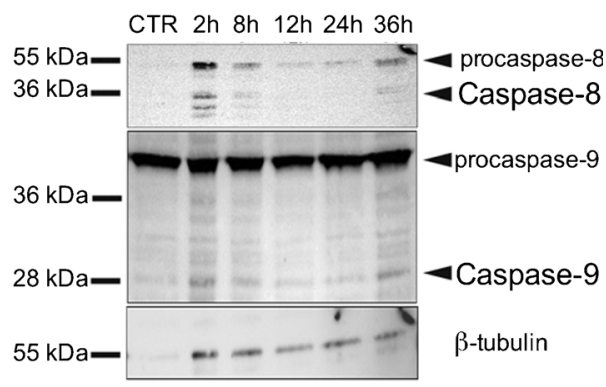

A673

143.98.2 OS Cells

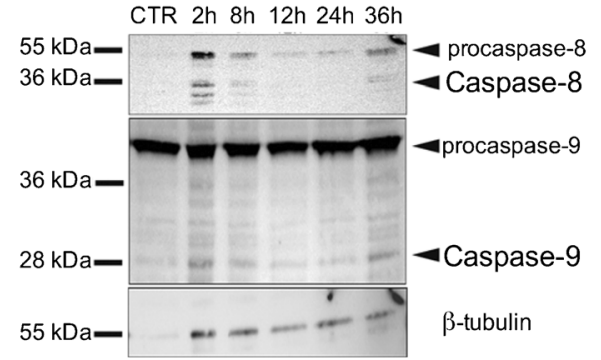

C

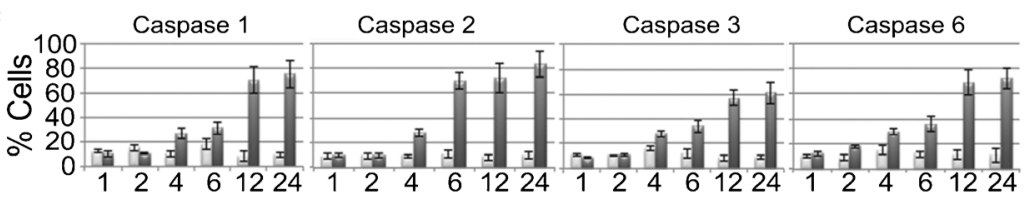

Time (h)

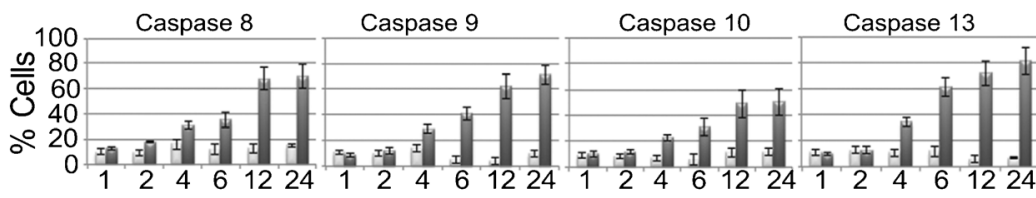

Control

Time (h)

Fig. 3 Induction of Apoptosis by RC 16 . (a) Annexin V-FITC/7ADD stained fluorescence-activated cell sorter (FACS) in SH-SY5Y, A673 cells and I 43.98.2 cells. All the samples were treated with $5 \mu \mathrm{M} \mathrm{RC} \mathrm{C}_{16}$ for 15 and $24 \mathrm{~h}$. (b) Western blot analysis of SH-SY5Y cells treated with $5 \mu \mathrm{M} \mathrm{RC}_{16}$ for 2, 8, I2, 24 and $36 \mathrm{~h}$ for caspase 3, 8 and 9. H3h, H9h: Hela treated with $5 \mu \mathrm{M}$ staurosporine for 3 and $9 \mathrm{~h}$ (positive control of apoptosis); S9h: SH-SY5Y treated with $5 \mu \mathrm{M}$ staurosporine for $9 \mathrm{~h}$ (positive control of apoptosis). (c) Fluorimetric assay of caspases I , 2, 3, 6, 8, 9, I0, I3 activation in SH-SY5Y cells treated with RC $165 \mu$ M for I , 2, 4, 6, I2 and $24 \mathrm{~h}(\mathrm{p}<0.05)$.

\section{Pharmacokinetics and Biodistribution of $\mathbf{R C}_{16}$}

The pilot pharmacokinetic data were obtained after $\mathrm{RC}_{16}$ administration at $1 \mathrm{mg} / \mathrm{kg}$ in mice by i.v. or $2 \mathrm{mg} / \mathrm{kg}$ by oral route. Each data point is from a single mouse. At $2 \mathrm{~h}$ post i.v. administration, the plasma concentration was $153 \mathrm{ng} / \mathrm{mL}$ with a continued decline to $11.4 \mathrm{ng} / \mathrm{mL}$ by $24 \mathrm{~h}$ and a measured half-life of $5.4 \mathrm{~h}$ (Fig. 6a). After oral administration the maximum observed plasma concentration of $\mathrm{RC}_{16}$ was $12.5 \mathrm{ng} / \mathrm{mL}$ at $4 \mathrm{~h}$. The concentration continued to decline and was measured at $0.5 \mathrm{ng} / \mathrm{mL}$ and $4.6 \mathrm{ng} / \mathrm{mL}$ in the plasma samples collected from the mice euthanized at 24 and 48 h, respectively (Fig. 6a). Noncompartmental analysis of these pilot data indicated an apparent half-life of $5.2 \mathrm{~h}$, similar to that from intravenous dosing. The pharmacokinetic parameters of $\mathrm{RC}_{16}$ following intravenous and oral administration in nude mice are summarized in Fig. 6b.

Bioluminescence images showed an extensive distribution of fluorescence in the whole body at $12 \mathrm{~h}$ and a gradual decrease of distribution at 24 and $36 \mathrm{~h}$ with a persistence of fluorescence in the liver and the gastrointestinal system (Fig. 6c). For a quantitative evaluation of biodistribution the organs were removed from the euthanized mice at 12, 24 and $48 \mathrm{~h}$ after i.v. injection of the labelled $\mathrm{RC}_{16}$ and were imaged immediately after dissection. All images were acquired for $5 \mathrm{~s}$ and processed using the Xenogen Living Image software (25). The fluorescence intensity (photons/second, $(\mathrm{p} / \mathrm{s})$ ) was calculated per unit weight of each organ (26), and the results are shown in Fig. 6d. At each time point stomach, intestine and liver showed the highest fluorescence intensity. All the organs showed a decrease in $\mathrm{RG}_{16}$ content over time except the tumors whose $\mathrm{RG}_{16}$ level remained constant over time.

\section{In Viwo Efficacy Studies}

Prior to initiation of the experiment, animals were naive to drug and weighed an average of $0.023 \mathrm{~kg}$. Administration of 

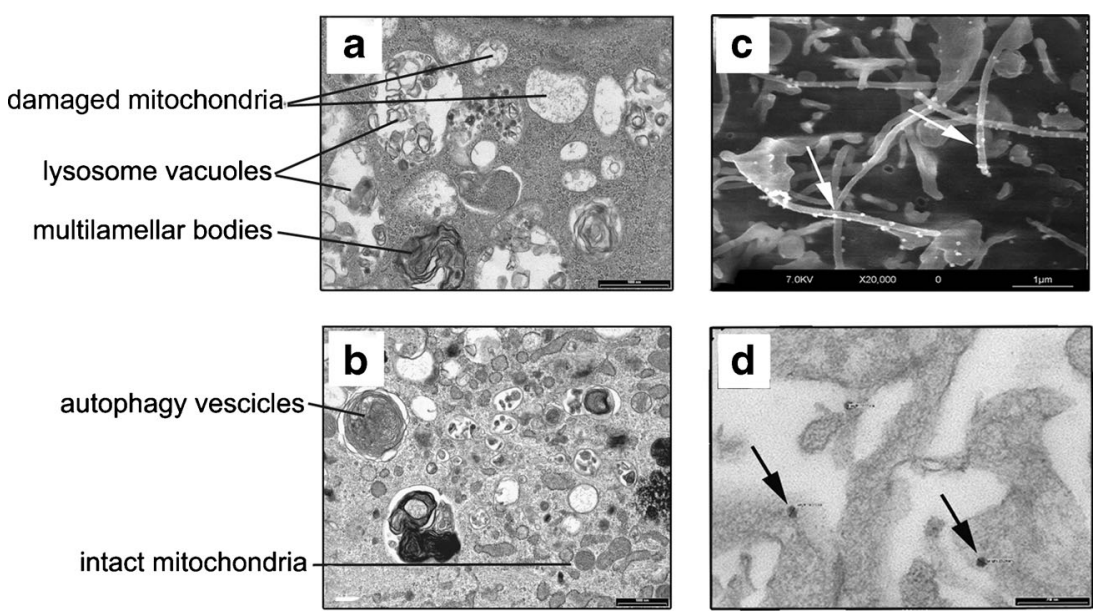

Fig. 4 Electron microscopic analysis of $\mathrm{RC}_{16}$ treated neuroblastoma cells. (a) TEM image of SH-SY5Y cells treated with $\mathrm{RC}_{16}$ at $24 \mathrm{~h}$ showing damaged mitochondria, multilamellar bodies and lysosomes (bar: $100 \mathrm{~nm}$ ). (b) TEM image of human fibroblasts treated with $\mathrm{RC}_{16} 5 \mathrm{M}$ at $24 \mathrm{~h}$ showing a preserved

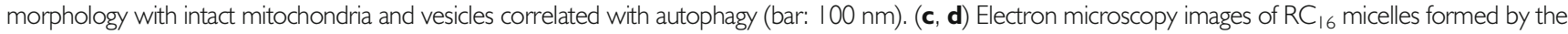
spontaneous self-assembling of the amphiphilic $\mathrm{RC}_{16}$ in the presence of SH-SY5Y cells with $20 \mu M \mathrm{RC}_{16}$. SEM image(C, bar: I $\left.\mu \mathrm{m}\right)$, TEM image (D, bar: $200 \mathrm{~nm}$ ). Arrows indicate the presence of micelles on the cell surface.

$\mathrm{RG}_{16}$ to six mice bearing human tumor xenografts in each treatment group demonstrated a strong antitumor activity by both intravenous and oral administration (Fig. 7a). No weight loss or signs of toxicity were observed in any case during the treatment period indicating good tolerability of $\mathrm{RC}_{16}$ both by intravenous administration and gavage. In the metastatic model of neuroblastoma disease the mice showed a significant increase in the mean survival time with respect to the controls (Fig. 7b) indicating a strong activity of $\mathrm{RC}_{16}$ after a single intravenous administration. At the end of the experiment (90 days) 3 of the $12 \mathrm{RC}_{16}$ treated mice were healthy and alive and showed no evidence of macroscopic disease at necropsy.

\section{DISCUSSION}

We created and tested a novel class of amphiphilic amines ( $\mathrm{RCn}$ ) based on a tricyclic hydrophilic head and a hydrophobic alkyl linear tail of variable length for their antitumor activity and their ability to complex bioactive molecules. We observed anticancer activity of the RCn amines in all of the cancer cell lines analysed, including both pediatric and adult tumors, greater than seen in the normal cells.

$\mathrm{RC}_{16}$, characterized by an intermediate alkyl tail length, exhibited the strongest anticancer activity in the series and was chosen as a lead compound for further study. $\mathrm{RC}_{16}$ exhibited significant antitumor activity in several cancer models by both intravenous and oral routes. Mechanistic studies suggest $\mathrm{RC}_{16}$ binds to sialic acid residues on the cell membrane and induces cell death via mitochondrial and lysosomal damage. Both activities are likely to account for the differential effects on tumor compared with normal cells. The interaction with sialic acid is an interesting target in cancer research as it enables selectivity for tumor cells due to high levels of the polysialilated glycoproteins and gangliosides on their surface. The interaction of $\mathrm{RC}_{16}$ with sialic acid may be attributed to the presence of the 4-membered azetidine ring on its hydrophilic head that links the polysialic acid residues of the tumor cell membranes (27-29). Indeed azetidines are known to easily react with nucleophiles undergoing acid catalyzed ring opening reactions (30-32) due to their high ring strain energy, especially in the presence of substitution like in $\mathrm{RC}_{16}$ where the substituent is represented by a cyclic structure. The $\mathrm{RC}_{16}$ interaction with polysialic acid is expected to produce structural modifications on the glycoproteins and gangliosides of the tumor cell surface thus inducing perturbations to the functional properties of the cell membrane that, in addition to the other alterations induced in mitochondria and lysosomes, contribute to the final antitumor activity of $\mathrm{RC}_{16}$. In normal cells, on the contrary, the very limited expression of sialic acid avoids any significant interaction of $\mathrm{RC}_{16}$ with the cell surface.

The molecular mechanisms underlying the observed intracellular effects are not completely clear, but the particular

Table III Cell killing activity of Doxorubicin, Paclitaxel and Etoposide Complexed with $\mathrm{R}_{-} \mathrm{C}_{16}$ *

\begin{tabular}{llll}
\hline Complex & \% CTR & Free drug & $\%$ CTR \\
\hline RC16-DOXO & $11.63 \pm 1.29$ & DOXO & $27.62 \pm 0.55$ \\
RC16-PTX & $40.34 \pm 3.51$ & PTX & $56.93 \pm 4.61$ \\
RC16-ETO & $35.26 \pm 2.08$ & ETO & $65.80 \pm 5.76$ \\
\hline
\end{tabular}

*CHLA-20 cells were seeded in 96 well plates $\left(2 \times 10^{4}\right.$ cells /plate $)$ and after $24 \mathrm{~h}$ they were treated with the complexes $(3 \mu \mathrm{M})$ or with the free drugs at concentrations corresponding to those present in the complexes. After $48 \mathrm{~h}$, the effect on cell number was evaluated by MTT assay. Cell viability was expressed as a percent of the untreated CHLA-20 cells (CTR). Data are representative of three independent experiments $(p<0.05)$ 


\section{a}
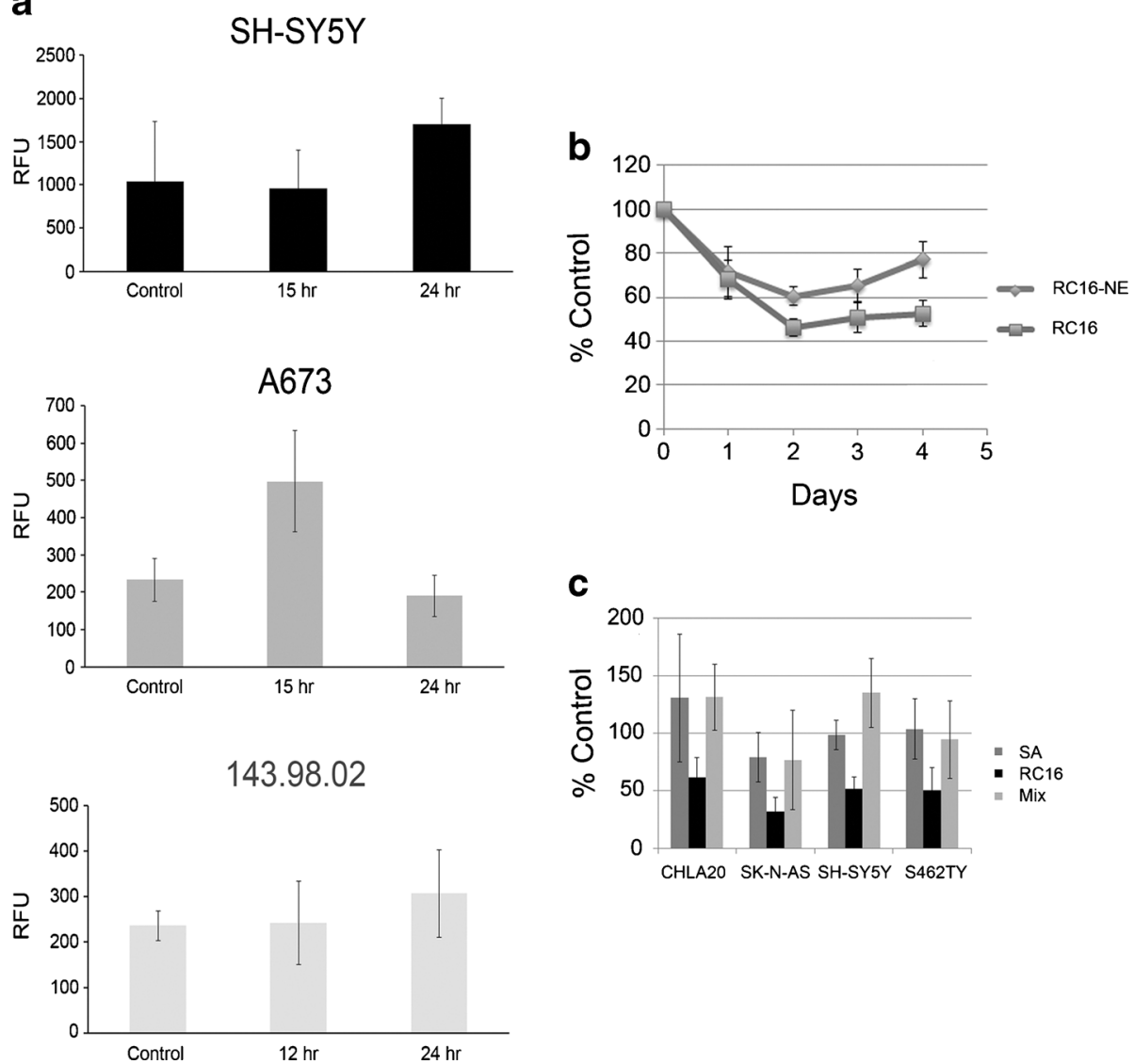

CHLA20 SK-N-AS SH-SY5Y S462TY

Fig. 5 Evaluation of intracellular ROS and the interaction of $\mathrm{RC}_{16}$ with sialic acid. (a) Measurement of intracellular ROS in A673, 143.98.2 and SH-SY5Y after treatment with $5 \mu \mathrm{M} \mathrm{RC} C_{16}$ for $15 \mathrm{~h}$ or $24 \mathrm{~h}$. $(p<0.05)$. (b) Anticancer effect of $\mathrm{RC}_{16}(3 \mu \mathrm{M})$ on S462.TY cells $\left(\mathrm{RC}_{16}\right)$ in comparison with the same cells previously treated with Neuraminidase $(50 \mathrm{mU} / \mathrm{ml})\left(\mathrm{RC}_{16}-\mathrm{NE}\right)$. (c) Tumor cells treated with $\mathrm{RC}_{16}(3 \mu \mathrm{M})$ or a mixture of $\mathrm{RC}_{16}+\operatorname{Sialic} \mathrm{Acid}(3 \mu \mathrm{M}: 3 \mu \mathrm{M})$ or pure Sialic Acid $(3 \mu \mathrm{M})$ for $24 \mathrm{~h}$.

molecular structure of $\mathrm{RC}_{16}$ may account for its multiple mechanisms of action. Indeed $\mathrm{RG}_{16}$, as the other $\mathrm{RCn}$, is comprised of 4, 6 and 7 membered rings condensed in a unique tricyclic assembly linked to an alkyl linear tail. The hydrophobic cycles surrounding the amine groups in the tricyclic assembly provide a counter-balance to the hydrophilicity increase triggered by the amine groups' protonation in an aqueous physiological environment thus allowing the molecules to partition through biological membranes in spite of the presence of positive charges. Thus the observed damage to the inner mitochondrial membranes and the increase in the cell ROS levels in the tumor cells may be attributed to an accumulation of $\mathrm{RC}_{16}$ in mitochondria. This accumulation might be promoted by both the negative transmembrane potential of the mitochondrial inner membrane (negative inside), which favors passage of protonated molecules into the matrix, and by the acidic $\mathrm{pH}$ of the intermembrane space which attracts amine molecules from the cytoplasm inside the mitochondria (14). Moreover, the high content of negatively charged phospholipids such as cardiolipin on the outer mitochondrial membrane might further favor accumulation of protonated molecules on the mitochondrial surface (33).
Similarly, the observed alterations of the lysosomes in the tumor cells treated with $\mathrm{RC}_{16}$ may be attributed to an accumulation of $\mathrm{RC}_{16}$ in the acidic inner environment of lysosomes driven by the same suitable hydrophilic/ hydrophobic balance of the molecule allowing its partition across the lysosomal membrane and a further protonation inside (10-13).

In addition to differential expression of sialic acid, we hypothesize that the differential effects of $\mathrm{RG}_{16}$ on tumor compared with normal cells are due to differences in organelle membrane potentials. We observed the mitochondria and lysosomes alterations and the ROS increase after treatment with $\mathrm{RG}_{16}$ in cancer cells but not in normal cells. This finding is in accordance with the observation that the mitochondria of cancer cells, in contrast to normal cells, are characterized by a very large membrane potential across the mitochondrial membrane (up to $150-160 \mathrm{mV}$, negative inside) driving an extensive uptake of partitionable amines within the mitochondrial matrix (14-16). Likewise, the lysosomes of cancer cells are characterized by an increase in lysosomal enzymes and a deregulation of the enzymatic functions which, providing acidification defects and metabolic perturbations, may make 


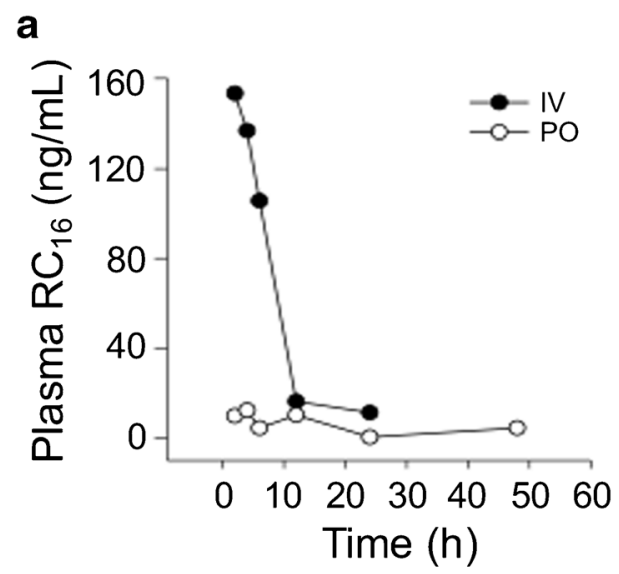

b

\begin{tabular}{lcc}
\hline Parameter & IV & PO \\
\hline Half-life $\left(\mathrm{t}^{1 / 2}, \mathrm{hr}\right)$ & 5.4 & 5.2 \\
$\mathrm{C}_{\max }(\mathrm{ng} / \mathrm{mL})$ & 153 & 12.5 \\
$\mathrm{AUC}_{0-24}(\mathrm{hr} * \mathrm{ng} / \mathrm{mL}$ & 1391 & 160 \\
\hline
\end{tabular}

C

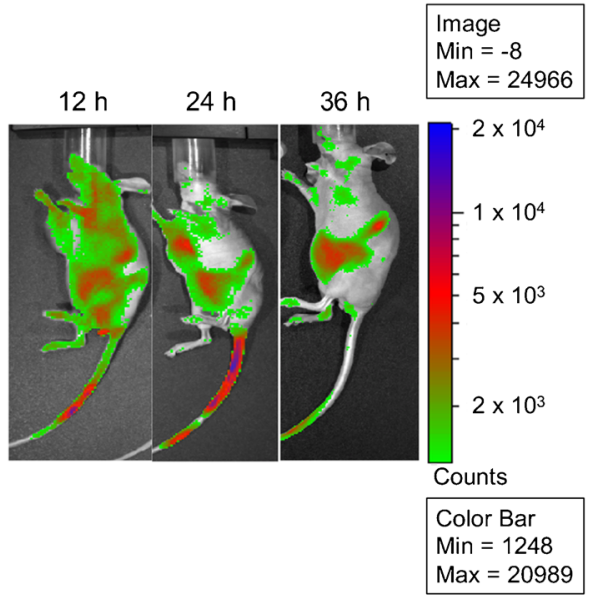

d

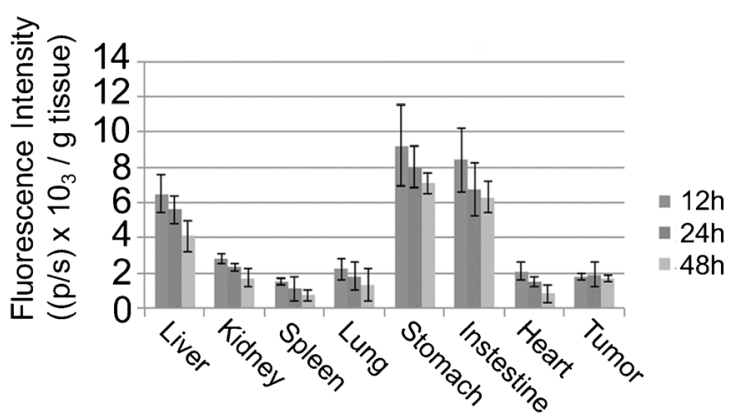

Fig. 6 Pharmacokinetic and biodistribution studies of $\mathrm{RC}_{16}$ in mice. Plasma concentration-time profiles of $\mathrm{RC}_{16}$ after intravenous or oral (a) administration at I mg/kg or $2 \mathrm{mg} / \mathrm{kg}$ respectively ( $n=1$ mouse per time point). (b) Non-compartmental pharmacokinetic parameters of $R C_{16}$. $t_{1 / 2 \alpha}$ and $t_{1 / 2 \beta}$ represent half-lives in the initial distribution phase and in the subsequent elimination phase respectively; $C_{0}$ is the initial drug concentration in blood; $V_{d}$ is the volume of distribution; AUC is the area under the blood concentration versus time curve. (c) Biodistribution of $R_{16}$ labelled with Cell-Vue Maroon (dye: $R C_{16}$ l:100 mol:mole) in nude mice bearing CHLA-20 tumors $(n=3)$. The labelled $R C_{16}$ was injected i.v. at I mg/kg and whole-body images of the mice were taken at 12,24 and 36 h after i.v injection. (d) Fluorescence intensity in tissues and organs at 12, 24 and 48 h after the i.v. injection of RC 16 labelled with Cell-Vue Maroon.

the lysosomal structure more sensitive to the accumulation of partitionable amines $(17,18)$. The mechanism of cell death induced by $\mathrm{RC}_{16}$ appears to be mostly via apoptosis, involving the activation of initiator caspases (caspase-2, caspase-8, caspase-9, caspase-10), executioner caspases (caspase-3, caspase6) and also pro-inflammatory caspases (caspase- 1 and caspase13). The role of the pro-inflammatory caspases in cell death is likely related to their ability to induce host inflammatory responses in vivo, thus their contribution to cell death may be observed in vivo but not in vitro. While the ability to accumulate into the mitochondria and the lysosomes of tumor cells is present in other amine-type antitumor drugs such as the Delocalized Lipophilic Cations (Rodhamine, MKT-077 F16 and Dequalinium) and the Lysosomotropic Drugs (Chloroquine and MDL 72527) (32,34-37), the ability to interact with sialic acid is unique to $\mathrm{RC}_{16}$.

The generalized nature of the effects of $\mathrm{RC}_{16}$ may have a distinct advantage over drugs that attack specific molecular targets as it may be more difficult for cells to develop resistance. Cells are able to develop resistance to drugs that bind DNA, RNA or RTKs through the expression of P-glycoprotein, Multidrug-Resistance associated Proteins, activation of alternative RTK pathways, or acquisition of non-binding mutations (7). Down-regulation of sialic acids may be a mechanism whereby cells could escape the effects of $\mathrm{RC}_{16}$, though such global dysregulation may not be compatible with the tumorigenic phenotype.

It will likely be possible to further increase the therapeutic efficacy of $\mathrm{RC}_{16}$. For example, we did not optimize drug exposure by maintaining constant drug plasma concentrations over time as the well known limitations imposed by the mouse models make it difficult to test a continuous infusion regimen. Without continuous infusion, it is possible to reach plasma drug concentrations in the therapeutic window for limited periods of time followed by decrease in concentration which may allow the tumor mass to resume its growth. $\mathrm{RC}_{16}$ distributes to the gastrointestinal tract, liver and kidney due to its amine character which, following protonation, drives the $\mathrm{RG}_{16}$ circulating molecules into the distribution pathway of the cationic compounds. In this pathway a major role is played by the organic cation transporters (OCT1 and OCT2) which are highly expressed in basolateral membranes of hepatocytes, intestine enterocytes and renal proximal tubular cells and mediate the elimination of a variety of cationic compounds such 
a
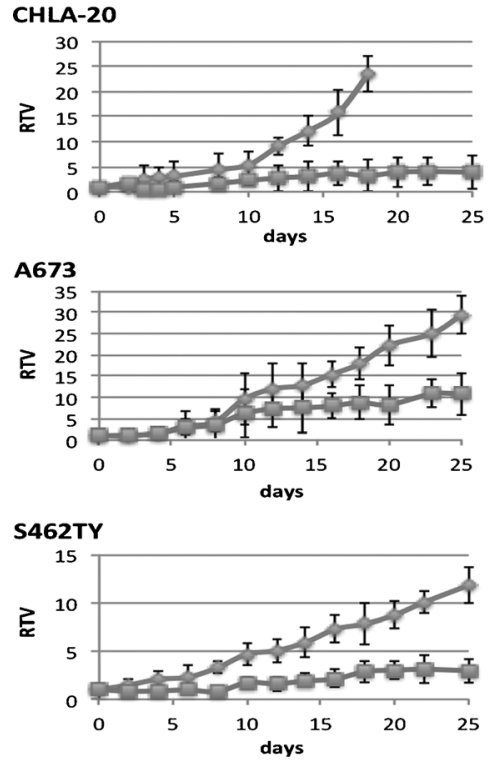

SK-N-AS

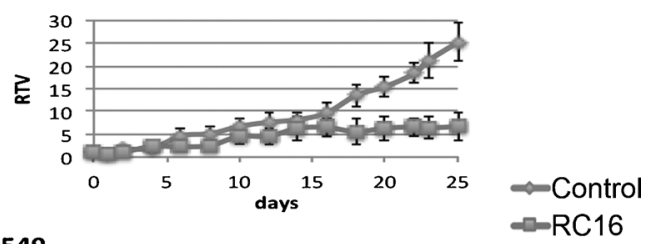

A549

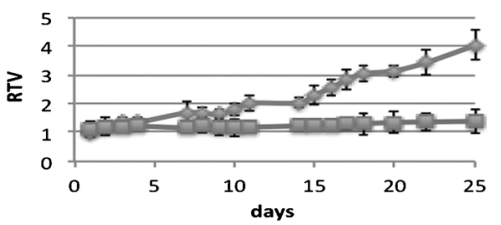

CHLA-20 (oral route)

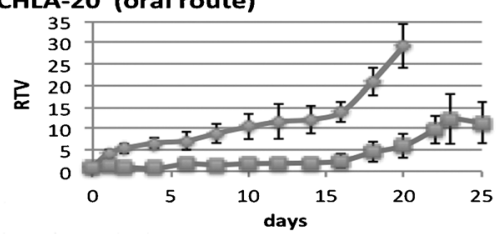

b

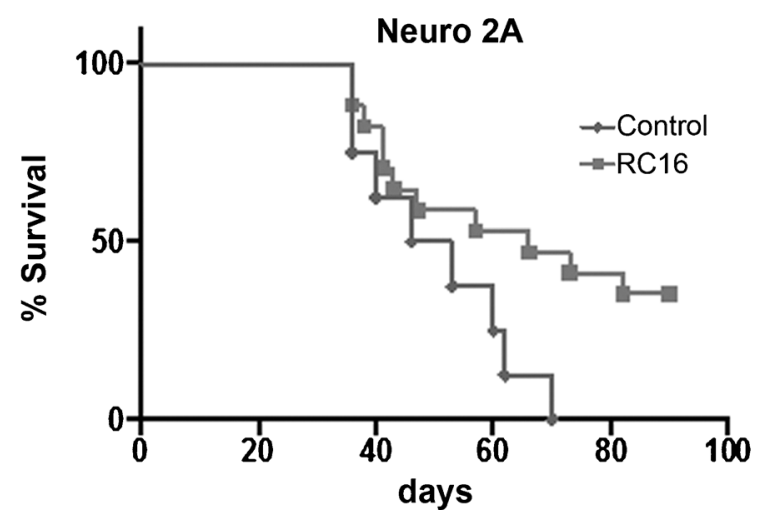

Fig. 7 Evaluation of $\mathrm{RC}_{16}$ for in vivo efficacy. (a) Inhibition of the tumor growth in tumor xenograft models by intravenous administration (CHLA-20, SK-N-AS, $\mathrm{A} 673, \mathrm{~A} 549, \mathrm{~S} 462 \mathrm{TY}$ ) or oral administration (CHLA-20) of $\mathrm{RC}_{16} \cdot \mathrm{RC}_{16}$ was given through the tail vein at the dose of I $\mathrm{mg} / \mathrm{kg}$, 3 times a week for 3 weeks or gavaged at the dose of $2 \mathrm{mg} / \mathrm{kg} /$ day for 3 weeks. $R T V$ is obtained by $T V n / T V_{0}$, where $T V n$ is the tumor volume at day $n$ and $T V_{0}$ is the tumor volume at day 0$)(P-$ values $<0.05$ ). (b) Improvement of the survival in a metastatic model of murine neuroblastoma (Neuro-2A) by intravenous administration of $R C_{16}$. $R C_{16}$ was injected through the tail vein at doses of $20 \mu \mathrm{g}(n=6)$ or $40 \mu \mathrm{g} /$ mouse $(n=6)$ (plotted together) $(p$-values $<0.05)$.

as drugs, toxins, and endogenous molecules (38), but whether they play a role in RC16 metabolism is unknown. Although a limitation of the study is that we only tested one mouse per timepoint, the pilot pharmacokinetic data demonstrated we were able to achieve concentrations in the 150 to $200 \mathrm{ng} / \mathrm{mL}$ range (approximately 500-600 $\mathrm{nM}$ ) at the low i.v. dose of $1 \mathrm{mg} / \mathrm{kg}$. Oral dosing with $\mathrm{RG}_{16}$ may be worth further study, as we did estimate an oral bioavailability of approximately $6 \%$ based on the pilot pharmacokinetic data. We have not determined an MTD for this route of administration, and higher doses that could produce similar or even greater plasma exposures may be achievable via oral gavage.

In addition to its activity as an antitumor drug, $\mathrm{RC}_{16}$ has been evaluated for its ability to complex other bioactive molecules such as Doxorubicin, Etoposide and Paclitaxel. The complexation ability of $\mathrm{RC}_{16}$ is based on its amphiphilic character triggering a spontaneous self-assembling of molecules in water with formation of micelles. As it is well known that micelles with a hydrophobic inner core and a hydrophilic outer shell may encapsulate hydrophobic or partially hydrophobic drugs $(39,40)$, forming micellar aggregates also referred to as complexes, complexation of poorly water soluble drugs into the micelles may improve their aqueous solubility and consequently their bioavailability and therapeutic efficacy (41-46). Micellar complexation may moreover modify the drug disposition in the body by preventing uncontrolled drug distribution and favoring drug accumulation in solid tumors where the discontinuity of the capillaries and the lack of an efficient lymphatic drainage supports the entrapment and retention of nanoparticulate systems such as micelles, liposomes or soluble macromolecules $(39,40,47)$. The micellar complexation of Paclitaxel and Etoposide is regarded with 
great interest to improve their bioavailability $(48,49)$ overcoming the adverse reactions associated with the currently marketed formulations. Indeed, apart from Abraxane ${ }^{\circledR}$, consisting in nanoparticles of Paclitaxel and human serum albumin, all the other marketed formulations of Paclitaxel and Etoposide contain excipients such as Cremophor-EL, ethanol, benzyl alcohol, polysorbate- 80 which have been associated with serious side effects (50). The micellar complexation of Doxorubicin is also considered a very interesting approach but in this case the main purpose is a modification of the drug biodistribution in addition to an increase in its solubility. Indeed Doxorubicin induces a strong dose-limiting cardiotoxicity (51), and its encapsulation in micelles or liposomes has proven to decrease its distribution to the heart with a reduction of its cardiotoxic effect (52). Simultaneously, increased solubility by micellar complexation has proven to enhance its therapeutic activity (53).

In summary, we have developed a novel, multimechanistic antitumor drug class that shows promise for cancer therapy. These amphiphilic amines bind to and induce anticancer activity by several mechanisms of action with differential effects on normal cells, resulting in a clinically significant therapeutic window. Furthermore, these agents are useful for encapsulating traditional chemotherapies and thereby enhancing their efficacy and reducing their side-effects.

\section{COMPLIANCE WITH ETHICAL STANDARDS}

Financial Support This project was funded by the Cancer Free Kids Pediatric Cancer Research Foundation (Cincinnati, $\mathrm{OH})$ and by Cincinnati Children's Hospital Medical Center, The Research Institute at Nationwide Children's Hospital and the Ohio State University Comprehensive Cancer Center Core Grant (P30 CA016058) Pharmacoanalytical Shared Resource.

Disclosure of Potential Conflict of Interest Patent serial no. PCT/ US2014/071937 was filed on 12/22/2014 with Drs. Cripe and Orienti and Mr. Currier as inventors of the technology described in this report.

Open Access This article is distributed under the terms of the Creative Commons Attribution 4.0 International License (http://creativecommons.org/licenses/by/4.0/), which permits unrestricted use, distribution, and reproduction in any medium, provided you give appropriate credit to the original author(s) and the source, provide a link to the Creative Commons license, and indicate if changes were made.

\section{REFERENCES}

1. Sleijfer S, Bogaerts J, Siu LL. Designing transformative clinical trials in the cancer genome era. J Clin Oncol. 2013;31:1834-41.

2. Awada A, Aftimos PG. Targeted therapies of solid cancers: new options, new challenges. Curr Opin Oncol. 2013;25:296-304.

3. Smith MA, Seibel NL, Altekruse SF, Ries LA, Melbert DL, O'Leary M, et al. Outcomes for children and adolescents with cancer: challenges for the twenty-first century. J Clin Oncol. 2010;28: 2625-34.

4. Jemal A, Simard EP, Dorell C, Noone AM, Markowitz LE, Kohler $\mathrm{B}$, et al. Annual report to the nation on the status of cancer, 19752009, featuring the burden and trends in human papillomavirus (HPV)-associated cancers and HPV vaccination coverage levels. J Natl Cancer Inst. 2013;105:175-201.

5. Salehan MR, Morse HR. DNA damage repair and tolerance: a role in chemotherapeutic drug resistance. Br J Biomed Sci. 2013;70:31-40.

6. Yousif LF, Stewart KM, Kelley SO. Targeting mitochondria with organelle-specific compounds: strategies and applications. Chembiochem. 2009;10(12):1939-50.

7. Tredan O, Galmarini CM, Patel K, Tannock IF. Drug resistance and the solid tumor microenvironment. J Nat Cancer Inst. 2007;99: 1441-54.

8. Sun X, Wong JR, Song K, Hu J, Garlid KD, Chen LB. AAl, a newly synthesized monovalent lipophilic cation, expresses potent in vivo antitumor activity. Cancer Res. 1994;54:1465-71.

9. Duvvuri M, Konkar S, Hong KH, Blagg BS, Krise JP. A new approach for enhancing differential selectivity of drugs to cancer cells. ACS Chem Biol. 2006;1:309-15.

10. Duvvuri M, Krise JP. A novel assay reveals that weakly basic model compounds concentrate in lysosomes to an extent greater than $\mathrm{pH}$-partitioning theory would predict. Mol Pharm. 2005;2:440-8.

11. Marceau F, Bawolak MT, Lodge R, Bouthillier J, Gagné-Henley A, Gaudreault RC, et al. Cation trapping by cellular acidic compartments: beyond the concept of lysosomotropic drugs. Toxicol Appl Pharmacol. 2012;259:1-12.

12. Arai K, Yasuda N, Isohashi F, Okamoto K, Ohkuma S. Inhibition of weak-base amine-induced lysis of lysosomes by cytosol. J Biochem. 2002;132:529-34.

13. Logan R, Kong A, Krise JP. Evaluating the roles of autophagy and lysosomal trafficking defects in intracellular distribution-based drug-drug interactions involving lysosomes. J Pharm Sci. 2013;102(11):4173-80.

14. Edeas M, Weissig V. Targeting mitochondria: strategies, innovations and challenges: the future of medicine will come through mitochondria. Mitochondrion. 2013;13:389-90.

15. Plyavnik NV, Shtil AA, Serebrennikova GA. Ether lipids as anticancer agents: focus on non-phosphorus cationic glycerolipids. Mini Rev Med Chem. 2006;6:533-42.

16. Modica-Napolitano JS, Aprille JR. Delocalized lipophilic cations selectively target the mitochondria of carcinoma cells. Adv Drug Deliv Rev. 2001;49:63-70.

17. Wilson PD, Hreniuk D, Lenard J. Reduced cytotoxicity of the lysosomotropic detergent $\mathrm{N}$-dodecylimidazole after differentiation of HL60 promyelocytes. Cancer Res. 1989;49:507-10.

18. Ndolo RA, Luan Y, Duan S, Forrest ML, Krise JP. Lysosomotropic properties of weakly basic anticancer agents promote cancer cell selectivity in vitro. PLoS One. 2012;7, e49366.

19. Rice AM, Currier MA, Adams LC, Bharatan NS, Collins MH, Snyder JD, et al. Ewing sarcoma family of tumors express adenovirus receptors and are susceptible to adenovirus-mediated oncolysis. J Pediatr Hematol Oncol. 2002;24(7): 527-33. 
20. Dickens DS, Cripe TP. Effect of combined cyclooxygenase-2 and matrix metalloproteinase inhibition on human sarcoma xenografts. J Pediatr Hematol Oncol. 2003;25(9):709-14.

21. Parikh NS, Currier MA, Mahller YY, Adams LC, Di Pasquale B, Collins $\mathrm{MH}$, et al. Oncolytic herpes simplex virus mutants are more efficacious than wild-type adenovirus Type 5 for the treatment of high-risk neuroblastomas in preclinical models. Pediatr Blood Cancer. 2005;44(5):469-78.

22. Mahller YY, Rangwala F, Ratner N, Cripe TP. Malignant peripheral nerve sheath tumors with high and low Ras-GTP are permissive for oncolytic herpes simplex virus mutants. Pediatr Blood Cancer. 2006;46:745-754.

23. Eshun FK, Gurrier MA, Gillespie RA, Fitzpatrick JL, Baird WH, Cripe TP. VEGF blockade decreases the tumor uptake of systemic oncolytic herpes virus but enhances therapeutic efficacy when given after virotherapy. Gene Ther. 17(7):922-9.

24. Shimojo N, Kondo C, Yamashita K, Hoshino T, Hayakawa T. Cytotoxicity analysis of a novel titanium alloy in vitro: adhesion, spreading, and proliferation of human gingival fibroblasts. Biomed Mater Eng. 2007;17(2):127-35.

25. Lee MS, Kwon EH, Choi HS, Kwon SH, Lee CH, Shim IS, et al. Quantification of cellular uptake and in vivo tracking of transduction using real-time monitoring. Biochem Biophys Res Commun. 2010;394:348-53.

26. Kenis S, D'hooghe M, Verniest G, Dang Thi TA, Pham The C, Van Nguyen T, et al. Synthesis of 1-alkyl-2(trifluoromethyl)azetidines and their regiospecific ring opening toward diverse $\alpha$-(trifluoromethyl)amines via intermediate azetidinium salts. J Org Chem. 2012;77:5982-92.

27. Seifert A, Glanz D, Glaubitz N, Horstkorte R, Bork K. Polysialylation of the neural cell adhesion molecule: interfering with polysialylation and migration in neuroblastoma cells. Arch Biochem Biophys. 2012;524:56-63.

28. Falconer RA, Errington RJ, Shnyder SD, Smith PJ, Patterson LH. Polysialyltransferase: a new target in metastatic cancer. Curr Cancer Drug Targets. 2012;12:925-39.

29. Cantù L, Del Favero E, Sonnino S, Prinetti A. Gangliosides and the multiscale modulation of membrane structure. Chem Phys Lipids. 2011;164:796-810.

30. Ghorai MK, Das K, Shukla D. Lewis acid-mediated highly regioselective SN2-Type ring-opening of 2-aryl-N-tosylazetidines and aziridines by alcohols. J Org Chem. 2007;72:5859-62.

31. Vargas-Sanchez M, Lakhdar S, Couty F, Evano G. Reaction of azetidines with chloroformates. Org Lett. 2006;8:5501-4.

32. Wang F, Ogasawara MA, Huang P. Small mitochondria-targeting molecules as anti-cancer agents. Mol Asp Med. 2010;31:75-92.

33. Riedl S, Zweytick D, Lohner K. Membrane-active host defense peptides-challenges and perspectives for the development of novel anticancer drugs. Chem Phys Lipids. 201 1;164:766-81.

34. Kurtoglu M, Lampidis TJ. From delocalized lipophilic cations to hypoxia: blocking tumor cell mitochondrial function leads to therapeutic gain with glycolytic inhibitors. Mol Nutr Food Res. 2009;53:68-75.

35. Kimura T, Takabatake Y, Takahashi A, Isaka Y. Chloroquine in cancer therapy: a double-edged sword of autophagy. Cancer Res. 2013;73:3-7.

36. Agostinelli E, Seiler N. Lysosomotropic compounds and spermine enzymatic oxidation products in cancer therapy (review). Int J Oncol. 2007;31:473-84.
37. Funk RS, Krise JP. Cationic amphiphilic drugs cause a marked expansion of apparent lysosomal volume: implications for an intracellular distribution-based drug interaction. Mol Pharm. 2012;9: 1384-95.

38. Jonker JW, Schinkel AH. Pharmacological and physiological functions of the polyspecific organic cation transporters: OCT1, 2, and 3 (SLC22A1-3). J Pharmacol Exp Ther. 2004;308:2-9.

39. Torchilin VP. Micellar nanocarriers: pharmaceutical perspectives. Pharm Res. 2007;24:1-16.

40. López-Dávila V, Seifalian AM, Loizidou M. Organic nanocarriers for cancer drug delivery. Curr Opin Pharmacol. 2012;12:414-9.

41. Orienti I, Zuccari G, Falconi M, Teti G, Illingworth NA, Veal GJ. Novel micelles based on amphiphilic branched PEG as carriers for fenretinide. Nanomedicine. 2012;8:880-90.

42. Carosio R, Pistoia V, Orienti I, Formelli F, Cavadini E, Mangraviti $\mathrm{S}$, et al. Enhanced anti-neuroblastoma activity of a fenretinide complexed form after intravenous administration. J Pharm Pharmacol. 2012;64:228-36.

43. Orienti I, Zuccari G, Carosio R, Montaldo PG. Improvement of aqueous solubility of fenretinide and other hydrophobic anti-tumor drugs by complexation with amphiphilic dextrins. Drug Deliv. 2009;16:389-98.

44. Zuccari G, Bergamante V, Carosio R, Gotti R, Montaldo PG, Orienti I. Micellar complexes of all-trans retinoic acid with polyvinylalcohol-nicotinoyl esters as new parenteral formulations in neuroblastoma. Drug Deliv. 2009;16:189-95.

45. Orienti I, Zuccari G, Bergamante V, Fini A, Carosio R, Montaldo PG. Enhancement of oleyl alcohol anti tumor activity through complexation in polyvinylalcohol amphiphilic derivatives. Drug Deliv. 2007;14:209-17.

46. Orienti I, Zuccari G, Bergamante V, Mileo E, Lucarini M, Carosio R, et al. Amphiphilic poly(vinyl alcohol) derivatives as complexing agents for fenretinide. Biomacromolecules. 2006; 7:3157-63.

47. Lee SJ, Park K, Oh YK, Kwon SH, Her S, Kim IS, et al. Tumor specificity and therapeutic efficacy of photosensitizer-encapsulated glycol chitosan-based nanoparticles in tumor-bearing mice. Biomaterials. 2009;30:2929-39.

48. Singh S, Dash AK. Paclitaxel in cancer treatment: perspectives and prospects of its delivery challenges. Crit Rev Ther Drug Carrier Syst. 2009;26:333-72.

49. Ukawala M, Rajyaguru T, Chaudhari K, Manjappa AS, Pimple S, Babbar AK, et al. Investigation on design of stable etoposide-loaded PEG-PCL micelles: effect of molecular weight of PEG-PCL diblock copolymer on the in vitro and in vivo performance of micelles. Drug Deliv. 2012;19:155-67.

50. Strickley RG. Solubilizing excipients in oral and injectable formulations. Pharm Res. 2004:21:201-30.

51. Berthiaume JM, Wallace KB. Adriamycin-induced oxidative mitochondrial cardiotoxicity. Cell Biol Toxicol. 2007;23:15-25.

52. Sun Y, Zou W, Bian S, Huang Y, Tan Y, LiangJ, et al. Bioreducible PAA-g-PEG graft micelles with high doxorubicin loading for targeted antitumor effect against mouse breast carcinoma. Biomaterials. 2013;34:6818-28.

53. Gao X, Wang B, Wei X, Rao W, Ai F, Zhao F, et al. Preparation, characterization and application of star-shaped PCL/PEG micelles for the delivery of doxorubicin in the treatment of colon cancer. Int J Nanomedicine. 2013;8:971-82. 